\title{
Corrigendum: Heat Stress during Seed Filling Interferes with Sulfur Restriction on Grain Composition and Seed Germination in Oilseed Rape (Brassica napus L.)
}

\begin{abstract}
Sophie Brunel-Muguet ${ }^{1 *}$, Philippe D'Hooghe ${ }^{1}$, Marie-Paule Bataillé ${ }^{1}$, Colette Larré ${ }^{2}$, Tae-Hwan Kim ${ }^{1,3}$, Jacques Trouverie ${ }^{1}$, Jean-Christophe Avice ${ }^{1}$, Philippe Etienne ${ }^{1}$ and Carolyne Dürr ${ }^{4}$

' UCBN, INRA, UMR INRA-UCBN 950 Ecophysiologie Végétale, Agronomie and Nutritions N.C.S., Normandie University, Caen, France, ${ }^{2}$ INRA UR1268 BIA, Rue de la Géraudière, Nantes, France, ${ }^{3}$ Department of Animal Science, Environment-Friendly Agriculture Research Center, Institute of Agricultural Science and Technology, College of Agriculture and Life Science, Chonnam National University, Gwangju, South Korea, ${ }^{4}$ INRA, UMR 1345, Institute of Research on Horticulture and Seeds, Beaucouzé, France
\end{abstract}

Keywords: oilseed rape, sulfur, temperature, germination, grain quality, lipids, proteins, sugars

\section{OPEN ACCESS}

Edited by:

Laurent Deluc,

Oregon State University, USA

Reviewed by:

Richard William Bell,

Murdoch University, Australia

*Correspondence:

Sophie Brunel-Muguet

sbmuguet@rennes.inra.fr

Specialty section:

This article was submitted to Crop Science and Horticulture,

a section of the journal

Frontiers in Plant Science

Received: 20 October 2015

Accepted: 20 December 2015

Published: 12 January 2016

Citation:

Brunel-Muguet S, D'Hooghe P, Bataillé M-P, Larré C, Kim T-H,

Trouverie J, Avice J-C, Etienne P and

Dürr C (2016) Corrigendum: Heat

Stress during Seed Filling Interferes

with Sulfur Restriction on Grain

Composition and Seed Germination in

Oilseed Rape (Brassica napus L.).

Front. Plant Sci. 6:1236.

doi: 10.3389/fpls.2015.01236

\section{A corrigendum on}

Heat stress during seed filling interferes with sulfur restriction on grain composition and seed germination in oilseed rape (Brassica napus $\mathrm{L}$.

by Brunel-Muguet, S., D'Hooghe, P., Bataillé, M. P., Larré, C., Kim, T. H., Trouverie, J., et al. (2015). Front. Plant Sci. 6:213. doi: 10.3389/fpls.2015.00213

Reason for Corrigendum:

After our article was published online, it was brought to our attention that the values of the ratio $\omega 6 / \omega 3$ in Table 2 were inverted between the four treatments i.e., Ctrl T-HS, HT-HS, Ctrl TLS, and HT-LS. All of the other data related to the total FAs and the F-values for the FAs (in the Supplemental data, Table 2) are correct.

\begin{tabular}{lcccccccccccc}
\hline & Ctrl T-HS & HT-HS & & Ctrl T-LS & HT-LS & & T effect & S effect & T $\times$ S effect \\
\hline & mean & se & mean & se & mean & se & mean & se & & & \\
\hline $\begin{array}{l}C 18: 2 / C 18 / 3 \\
(\omega 6 / \omega 3)\end{array}$ & 1.82 & 0.32 & 2.47 & 0.12 & 1.70 & 0.03 & 3.11 & 0.32 & $17.2^{* * *}$ & $1.09 \mathrm{~ns}$ & $2.24 \mathrm{~ns}$ \\
\hline
\end{tabular}

Therefore, high temperature increased the ratio for both S supplies condition.

The authors apologize for the mistake that changes the conclusion with regards to the effect of temperature on this ratio.

In the text and in Figure 3, we want to make the following modifications:

In the abstract:

Instead of "While LS had negative effects on seed composition by reducing the FA contents and increasing the ratio S-poor SSPs (12S globulins)/S-rich SSPs (2S albumins) ratio, HT
Corrections for the values of the ratio $\omega 6: \omega 3$ follow: 
had positive effects by increasing $\mathrm{S}$ and FA contents and decreasing the $\mathrm{C} 18: 2 / \mathrm{C} 18: 3$ ratio and the $12 \mathrm{~S} / 2 \mathrm{~S}$ protein ratio," we want to write: "While LS had negative effects on seed composition by reducing the FA contents and increasing the ratio S-poor SSPs (12S globulins)/S-rich SSPs (2S albumins) ratio, HT had positive effects by increasing $\mathrm{S}$ and FA contents and decreasing the $12 \mathrm{~S} / 2 \mathrm{~S}$ protein but it negatively affected the $\mathrm{C} 18: 2 / \mathrm{C} 18: 3$ ratio by increasing it."

In the result section:

Page 5 line 500: Instead of "The C18:2/C18:3 (also denoted $\omega 6 /$ $\omega 3$, Table 2) ratio, which is used as an indicator of nutritional quality of oil (the lower the ratio, the higher the nutritional value), decreased significantly under heat stress under both $S$ treatments, while no significant effect of $\mathrm{S}$ was observed (Table 2)," we want to write "The C18:2/C18:3 (also denoted $\omega 6 / \omega 3$, Table 2) ratio, which is used as an indicator of nutritional quality of oil (the lower the ratio, the higher the nutritional value), increased significantly under heat stress under both $S$ treatments, while no significant effect of $S$ was observed (Table 2)."

In the discussion section:

Page 8 lines 846-849: Instead of "Our results also showed that heat stress was rather beneficial because it allowed the C18:2/C18:3 ratio to be lowered, which is usually targeted to satisfy dietary requirements (Simopoulos, 2002)," we want to

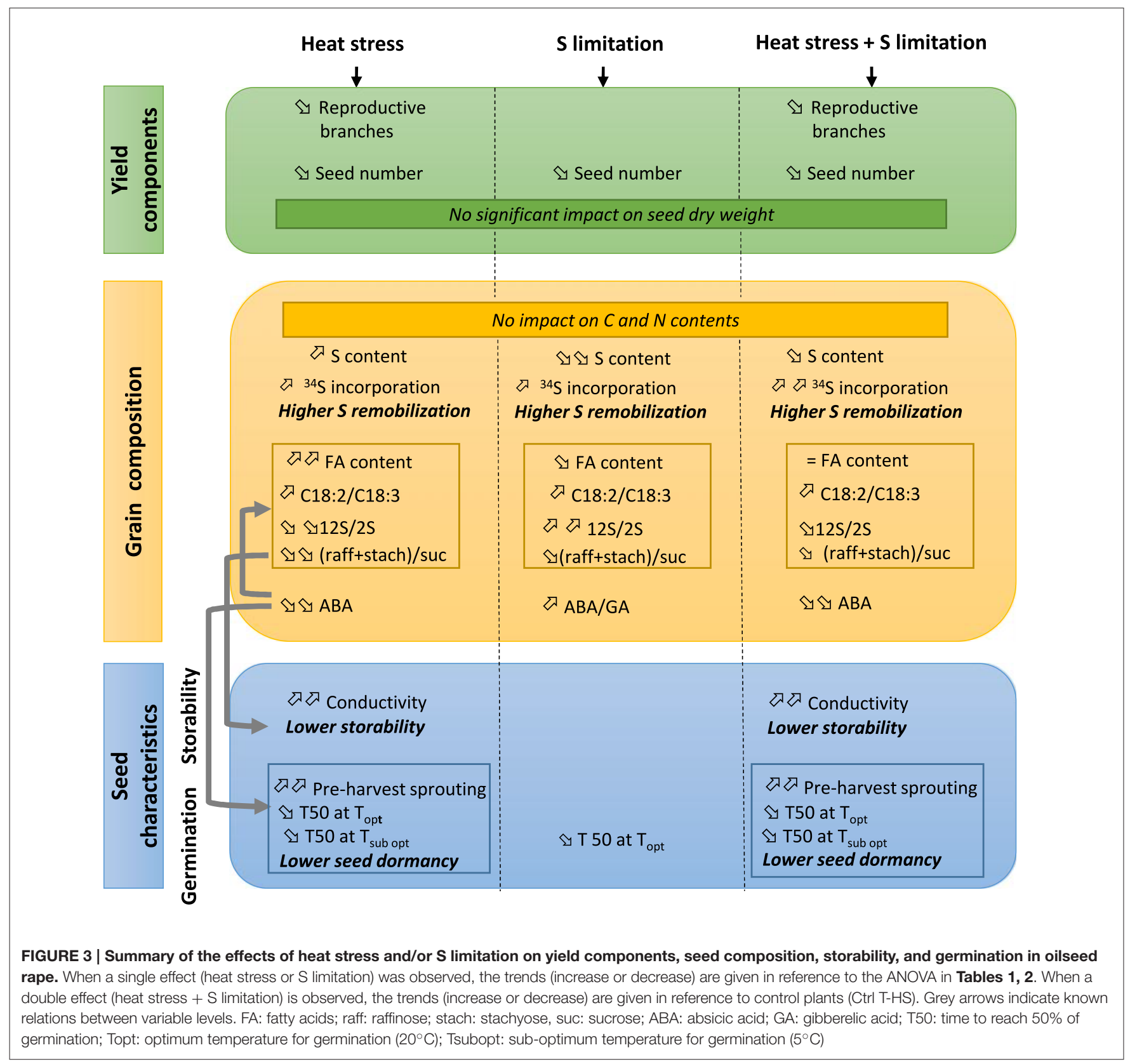


write "Our results also showed that heat stress was rather negative because it increased the $\mathrm{C} 18: 2 / \mathrm{C} 18: 3$ ratio, which is usually not targeted with regards to dietary requirements (Simopoulos, 2002)." Therefore, the following sentence is wrong "it should be noted that heat stress mitigated the negative effect of $\mathrm{S}$ restriction on the $\mathrm{C} 18: 2 / \mathrm{C} 18: 3$ ratio, as double stress (HT-LS) had torer C18:2/C18:3 ratios than single stressed seed.

Page 9 line 920: Instead of "Like the C18:2/C18:3 ratio, heat stress mitigated the negative effects of $S$ restriction (...)," we want to write "Heat stress mitigated the negative effects of $S$ restriction...."

Page 10 line 1030: instead of "Overall, heat stress decreased yield, but improved important ratios that determine the quality of the oil and meal (lipids and proteins)," we want to write: "Overall, heat stress decreased yield, but improved an important ratio that determine the quality meal (proteins)."

\section{In Figure 3}

The changes deal with the arrows for the C18:2/C18:3 ratios that increased with Heat Stress (first column) and with Heat Stress + S limitation (third column).

In addition to these points above, the authors want to correct the followings sentences:

- Page 2 line 148 (at the end of the first paragraph of the introduction): "S limitation may lead to a loss of $40 \%$ of seed yield in oilseed rape" instead of "S limitation may lead to $40 \%$ seed yield in oilseed rape."

\section{AUTHOR CONTRIBUTIONS}

$\mathrm{SB}, \mathrm{PD}, \mathrm{JT}, \mathrm{JA}$, and PE contributed to the experimental design, to plant growth and tissue sampling and have been involved in revising the article for important intellectual content. CD supervised the choice of relevant measurements on seeds. MB made the spectrometry analysis. CA was involved in the SSP analyses, interpretation of protein data, and revising the manuscript. TK was involved in the hormone measurements. SB performed the whole raw data analysis (including statistical analyses). SB and CD made interpretation of data and writing of the article.

\section{ACKNOWLEDGMENTS}

This work is part of the CAQ40 (CAQ40: Climate chAnge and Quality of fruit grain and seeds in the next 40 years) project, which was funded by the metaprogram ACCAF "Adaptation to Climate Change in Agriculture and Forest” by INRA.

Conflict of Interest Statement: The authors declare that the research was conducted in the absence of any commercial or financial relationships that could be construed as a potential conflict of interest.

Copyright (c) 2016 Brunel-Muguet, D’Hooghe, Bataillé, Larré, Kim, Trouverie, Avice, Etienne and Dürr. This is an open-access article distributed under the terms of the Creative Commons Attribution License (CC BY). The use, distribution or reproduction in other forums is permitted, provided the original author (s) or licensor are credited and that the original publication in this journal is cited, in accordance with accepted academic practice. No use, distribution or reproduction is permitted which does not comply with these terms. 